\title{
Monitoring plan gets low marks, low budget
}

Washington. An ambitious attempt by the US Environmental Protection Agency (EPA) to develop a comprehensive, national 'report card' for the environment is being scaled down following continuing criticism from both inside and outside the agency.

Some fear that the criticism may help to make the programme a potential target later this year as Congress searches for government programmes to axe.

The Environmental Monitoring and Assessment Program (EMAP) began in 1990 with a challenging goal: to establish a nationwide monitoring system that would provide scientists and policy-makers with fundamental, long-term data on ecological change. But after spending $\$ 135$ million over five years, the project is still far from reaching its goal.

Now a National Research Council panel, set up in 1991 to review EMAP, has stated that it "continues to question whether and how well [the project's] goals can be achieved". The panel, chaired by Richard Fisher of Texas A\&M University, will release next week its final report containing an overall assessment of the project.

Of EMAP's many problems, perhaps the most serious is that it has not yet identified which indicators it would use to measure ecological change across different kinds of ecosystems. This alone requires a great deal of research, according to the NRC panel. But EMAP has been slow to get started.
The panel also questions the proposed sampling methodology. It claims that this "may operate at too coarse a scale in space and time to detect meaningful changes in the condition of ecological resources", according to the group's final report.

Some of EMAP's woes are attributable to money. What was originally envisioned as a $\$ 100$ million per year programme has never

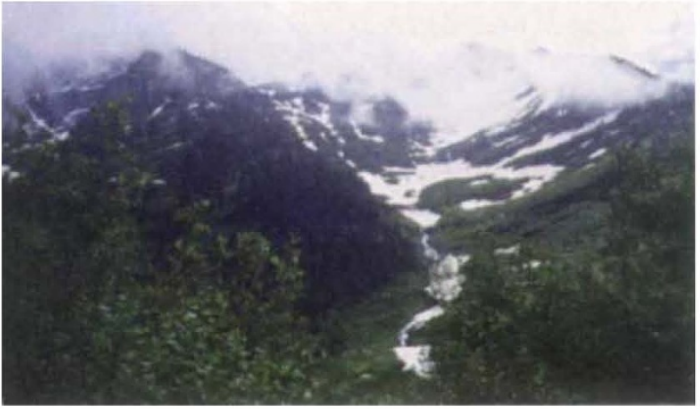

StIll waiting: proposals for a nationwide grid of monitoring sltes may be abandoned to cut costs. even come close. The project's 1995 budget was only a third of that amount.

But the NRC panel also details numerous administrative problems, including a lack of permanent staff assigned to the project and insufficient scientific advice from outside EPA. The end result is that after five years, EMAP has yet to come into focus. "They were still spending an awful lot of money answering very few fuzzy questions," according to one panel member.

\section{MIT links biologists to engineers}

Boston. The Massachusetts Institute of Technology (MIT) has set up a Center for Biomedical Engineering (CBE) intended to stimulate closer collaboration between research scientists, engineers and clinicians. In particular, the centre's programme is geared towards bringing engineering into closer contact with the most recent developments in cell and molecular biology.

"MIT has supported superb biomedical engineering work in the past, but the research was conducted by individuals scattered throughout the university," says the director of the new centre, Douglas Lauffenburger, himself a chemical engineer. "This work has never been coordinated through a single centre responsible for putting together multidisciplinary teams of biologists, chemists, and engineers."

The centre will focus on three general areas: molecular engineering, cell and tissue engineering and physiological systems. According to Lauffenburger, the centre is ideally situated for this kind of work, given the strengths in engineering, biology and medical research to be found at MIT and its Whitehead Institute, Harvard Medical
School and its affiliated hospitals, and other Boston institutions.

"It's hard to find another city in the world that is better placed in these three fields," he maintains. "There are many talented people here with a wide range of expertise. My job is to combine their skills in new ways with the eventual goal of improving health-care technology."

The centre was set up in January this year, but its new laboratory facilities will not be ready until the end of next year at the earliest. Nevertheless, many MIT faculty members from a variety of departments have already joined, and new research collaborations have formed as a result.

For example, Ian Hunter, a mechanical engineer at MIT who is an expert in smallscale robotic devices, has teamed up with Paul Matsudaira, a biologist at the Whitehead Institute, to develop new ways of studying the structural properties of proteins such as DNA. "Before the centre was created, neither was aware of the other's work," Lauffenburger says. "Ultimately, we hope to bring about interactions that have not even been considered previously." Steve Nadis
Even though programme managers say they are now implementing many of the recommendations in the NRC report, it may be a case of too little, too late. Robert Huggett, the new head of EPA's Office of Research and Development and himself an ecologist, has had his sights set on EMAP from the day he came to the agency.

Now, as he sets out to revamp EPA science - another NRC panel last month applauded these efforts Huggett has called for EMAP to be drastically restructured and scaled down. The idea of a nationwide grid of monitoring sites has been abandoned. In its place, the project would merely establish a few sites to take more in-depth measurements, while developing a set of scientifically valid indicators of ecological health.

With Huggett's restructuring in mind, Congress has already moved to reduce the programme's budget. A Senate bill expected to be approved this week rescinds $\$ 6$ million of the $\$ 37$ million already allocated to EMAP for this year.

When members of the Senate and the House of Representatives confer later this month to reconcile their two versions of the 'rescission' bill, the money for EMAP is unlikely to be restored. "I haven't had a single member [of Congress] come into my office to ask that the money be put back," says one congressional staff member who works on EPA's budget.

The fact that the Senate Appropriations Committee singled out EMAP, a relatively obscure programme, as a target for 1995 cuts suggests that the 1996 budget hearings - the agency is requesting $\$ 36$ million for the programme - will be even rougher. Huggett will shortly have to convince a sceptical Congress that EMAP, or whatever reduced research programme replaces it, is worth saving.

Tony Reichhardt

\section{Indian institutes to raise transfer efforts}

New Delhi. The Indian government has launched a Rs630 million (US\$20 million) scheme designed to help transfer knowledge from its leading academic institutions to the industrial arena.

The five Indian Institutes of Technology - in Madras, Delhi, Kharagpur, Kanpur and Bombay - as well as the Indian Institute of Science in Bangalore will each help to set up what is being described as a national mission for technology development and transfer.

In contrast to previous schemes, industry will be a major partner in the new programme, and will be expected to contribute 25 per cent of the costs of individual projects.

K.S. Jayaraman 